\title{
The Limits of Equality \\ The Intersectionality of Gender and Sexuality in Spanish Policy Making
}

Af Raquel Platero Méndez

The French Presidential candidate Segolene Royal called it "The Spanish Model of Equality" as opposed to the "Scandinavian Model". But what are the political strategies in which the seemingly progressive and transformative Spanish policies are framed? If one apply an intersectional perspective on Spanish equality laws and legislation on same-sex marriages what will then be the outcome?
T

the course of less than forty years, the Spanish political and cultural scenario has changed drastically, particularly in relation to civil rights. Social movements, especially feminist and LGBT (Lesbian, Gay, Bisexual, Transgender) organizations, have been successful in putting demands on the political agenda that have translated into gender equality, same-sex and transgender laws. Looking at definitions of equality, this article explores the implications of some postmodern theories that promote the analysis of political intersectionality for some of the recent laws that are presented as progressive and transformative in Spanish policy making. The analysis will explore two case studies: Samesex marriage and equality policy law texts, discussing the conception of intersectionality and equality. In addition, the definition of the feminist political strategy in which these policies are framed is addressed. Both case studies show that the policies are conceptualized within a liberal and assimila- 
tionist framework, since neither the male norm nor the sexual order is profoundly questioned.

\section{The Emergence of EQuality for Women and SEXual Minorities IN Spanish Public Policies}

Matters regarding civil rights, and women's rights in particular, have undergone a largescale transformation in Spain in recent history with key events like the democratization of the Spanish State and the Constitution of 1978, not to mention women's massive incorporation into the labor market and a dramatic positive change in women's access to education (Cruz and Zecchi 2004). Democracy brought about the beginning of formal equality; removing vestiges of a discriminatory legislation, assuming new shapes inspired by a reflective incipient feminist movement which emerged clandestinely and flourished in the seventies and eighties as well as facilitating the legalization of left-wing political parties and the freedom of association (Larumbe 2001; Escario et al. 1996). New equality legislation included sexual and reproductive rights with a focus on the decriminalization of and access to contraception (1974), divorce (1981), sex change (1983), abortion (1985), assisted reproduction (1988), etc. Furthermore, homosexual associations became legalized (1980), and the law on 'danger and social rehabilitation' was repealed in 1979. This law was applied massively to gay men and transsexuals, explicitly punishing male homosexuality, while lesbianism was mainly repressed in family scenarios by the Catholic Church and psychiatry. The law on public scandals remained operative until 1988, and in 1995 the law against homophobia took effect within the Penal Code (also called the Democracy Code), again amongst other necessary legal reforms and recognitions (Platero 2007b).

In opposition to certain feminisms that considered the State patriarchal and thus as catering only for the interests of men, there were women involved in 'double activism' who saw the State and its institutions as potential allies in the combat against discrimination (Bustelo 2004). From the beginning of the establishment of the Women's Institute (1983), equality policies grew popular as the main tool to address gender inequalities. The main political strategy employed by the Women's Institute at central and regional levels consisted of equality plans, "a number of initiatives that ought to followup horizontally actions taken by the different official bodies and institutions" (Bustelo and Peterson 2005). Many of the initiatives proposed by the Institute were developed through the different public institutions, and their level of success relies on the capacity of femocrats to 'sell' equality (Valiente 1995). The Institute together with the recently created General Secretariat of Equality Policies (2004) represent the main State machinery in the struggle toward gender equality. Both institutions were set up under Socialist governments within the Ministry of Work and Social Affairs. However, there has recently been a shift from 'soft' policies to 'hard' policies; the promotion of equality laws, the approval of specific plans - tackling violence, employment and family issues, social exclusion, etc. - and the creation of Gender Units in Andalusia and Cantabria (Bustelo and Peterson 2005, 2). This is also the scenario in which the first policies targeting gay men, lesbians, and transgender individuals emerged around 2000, mainly at local and regional levels. ${ }^{2}$

The focus on gender equality and sexual diversity is applied in a context in which public and political attention on citizens' diversity is on the increase. The socialist government, appointed in 2004, is addressing social demands linked to disability, immigration, the elderly, dependent individuals, etc. These social matters are becoming key issues for the current policy making. It has been said that this is a social legislature 
in which citizens' rights are becoming relevant - Spain is turning into a social laboratory of sexual freedoms (Osborne 2006) and that there is room for a definition of equality that has impact on e.g. women and sexual minorities (Platero 2007b).

In this article I address the development of gender equality policies, especially equality laws created from the year 2002, and the approval of same-sex marriage in Spain. Both examples are to help us observe how equality is 'framed,' taking into account any limitations in the definition of it as well as acknowledging the challenges faced by an intersectional analysis of the laws.

\section{INTERSECTIONALITY AND FEMINIST Political Strategies}

A number of experiences of exclusion that concern women help us to understand that there are power relations not only based on gender, but also on race, ethnicity, religion, migration, nationality, sexual orientation, gender identity, age, (dis)ability, class, etc. and that these experiences are interrelated and interact with each other. For some authors (see Verloo 2005), not all of these inequalities are on a par with one another: Gender structures and crosscuts them all.

Kimberlé Williams Crenshaw defined the concept of 'intersectionality' to denote the various ways in which race and gender interact to shape the multiple dimensions of Black women's employment experiences (Crenshaw 1989, 139). Her focus on the intersections of race and gender highlighted the need to account for multiple grounds of identity when considering how the social world is constructed. This approach was a way to escape from the identity politics that addressed problems monofocally: Neither feminism or antiracism movements managed to handle black women's issues. Crenshaw pointed out that identity politics frequently conflates or ignores intragroup differences, and therefore intersectional theory was not presented as a new totalizing theory of identities (1994), but rather as a complex perspective that acknowledges women's experiences of resistance and oppression.

A focus on intersectional perspectives helps us think about the impact of those policies designed for "collectives" or "ethnic-like" identities constructed around one single inequality, such as gender, sexuality, class, or migration. These inequalities are commonly addressed by means of monofocused policies (in Spain there are growing policy areas concerning gender equality, disability, immigration, employment, family, etc.) that do not take into account the complexity of people's lives. My interest is the way in which State reacts and recognizes inequalities by articulating actions to improve citizens' access to resources and rights; a process in which many problems remain invisible while others gain significance.

Crenshaw defined two different types of intersectionality: Structural and political intersectionality (Crenshaw 1994). Structural intersectionality focuses on people's experiences; how inequalities and the product of their intersections impact on their daily lives. Political intersectionality deals with the level of political strategies, although it does not offer a model to understand structures (Verloo 2005, quoting Beisel and Kay 2005). Using political intersectionality for analysis can provide us with a different perspective on identity, power, and equality, promoting a bottom-up approach to research, analysis, and planning (Symington $2004,5)$. This is the perspective that the article will take on in the analysis of political intersectionality. I will ask to what extent intersectionality - as a new theoretical framework/transformative policy frame - is taken into practice/consideration in the Spanish policy making of the specific law texts on same-sex marriage and equality policies.

In Spain, there seems to be a limited but growing interest for the concept and policy 
implications of 'multiple inequalities' and the possible relationship between gender, ethnicity, (dis)ability, class, etc. However, the use of the term and the concept of "intersectionality" is still modest. There are equality policy documents that use the expression "multiple discrimination" - such as the Basque $^{3}$ (1999) and Catalonian ${ }^{4}$ Equality Plans (2005) - whereas in the Anglo-Saxon world it is more common to focus on 'multiple inequalities.' In the Spanish language, the first term is most frequently used. However, the term 'multiple discrimination' does not cover the interactions between different inequalities, and focus on the issue of discrimination is privileged to their disregard. Acknowledging the interest for "double discrimination" regarding gender and sexuality, I have not found any use of the term 'intersectionality' (in Spanish 'interseccionalidad') in Spanish policy making; so far the term has not been used widely and is only found in research on postcolonialism and political theory 5 and in some human rights reports. ${ }^{6}$

One of the key changes that has taken place in the political transition to democracy in the seventies is the role played by women in Spanish society. The massive incorporation of women into the labor market and the incorporation of Spain into the international political and economical scenario have precipitated many changes, letting other social movements and rights develop, not only feminism but also LGBT rights, environmental awareness, human rights, etc. At the same time, migration, tourism, urbanism, and other socio-economic processes have relaxed social control over gender, sexuality, and morality, facilitating social changes in behavior. Spanish racial and multiethnic reality has been negated along with our colonial past in Latin America and Africa, paying little attention to minorities such as Romanis for instance (hooks 2004, 17). Nonetheless, some frames remained: The family ${ }^{7}$ continues to be the key institution of Spanish society, no matter how much the definition of family has changed to include single parents, homo-parental families, re-constituted unions, etc. In the Spanish context, it is no surprise that civil rights and demands are constructed within familial premises rather than as individual rights. All these changes have promoted a certain awareness of citizens' diversity in terms of gender, sexuality, age, ethnicity, language, etc. and the relevance of the State assuming responsibility for problems that arise.

Having introduced the intersectional perspectives, I would now like to introduce the work developed by Judith Squires (1999) regarding feminist political strategies. In Squires' overview of gender and political theory, she distinguishes between three analytically different feminist strategies: The strategy of 'inclusion,' based on the principle of equality; the strategy of 'reversal,' based on the principle of difference; and the strategy of 'displacement,' based on the principle of diversity. The 'inclusion' strategy correlates with antidiscrimination policies as this strategy aspires to impartiality (Verloo 2005); it is supported by liberal feminism, because it allows women into those realms from which they have traditionally been excluded. The impact vis-à-vis transforming society and institutions is limited, lacking of depth in questioning the gender norm (and others). The problem is located in 'women's (and other minorities') exclusion,' and the concomitant solutions are the different strategies that bring up more inclusion and parity.

The strategy of 'reversal' correlates with difference feminism by seeking recognition for a specific female gendered identity. This strategy pursues new institutions, new politics, and a whole problematization of the current frame of male domination. The problem identified is the so-called 'male norm.' Therefore, the solution aims to transform these patriarchal norms and pave the way for a recognition of women's identities and norms. 
As Verloo puts it, the strategy of 'displacement' aspires to move beyond gender, being rooted in postmodern analysis and poststructuralist feminism - as is intersectional analysis. It aims at deconstructing, destabilizing, and displacing oppositions embedded in concepts such as equality and difference, inclusion and reversal. This displacement strategy seeks to deconstruct regimes that 'engender' the subject. It aims at destabilizing the apparent opposition between equality and difference, between the strategies of inclusion and reversal, and seeks to displace patriarchal gender hierarchies and deconstruct discursive regimes that engender the subject. The strategy seeks to abolish binary categories of gender, sexuality, ethnicity, etc.

The three strategies in this typology differ in their underlying problem definitions and are not mutually exclusive. According to Squires and Verloo, the strategy of inclusion is fundamentally an integrationist and liberal approach, whereas only the strategies of reversal and displacement might be transformative. My analysis will point out how the selected policies are located in some of these strategies by looking at the accompanying problem definition. The intersectional perspectives will inform us of the extent to which a transformation of the policies is being pursued.

As it has been said before, there has been interest in 'double discrimination' and more recently in the impact of multiple discrimination, although the term intersectionality' has not been translated or used widely in the Spanish political scenario. In order to explore the extent in which this interest has impacted policy making I would like to use some of the 'hot' policies that were putting Spain under the international spotlight, constructing what Ségolène Royal called the 'Spanish model of equality' (made up of parity government, equality laws, and same-sex marriage $)^{8}$ versus the long-standing Scandinavian equality model.
The socialist government (PSOE) which came into power in 2004 set equality as a priority, presenting a parity - between men and women - government and addressing the demands of women's organizations (through, for example, the violence-integral Law9 1/2004); disability organizations (through changes in the terminology used regarding disability in the Constitution in 2006 , the promotion of a dependency law proposal, 10 the parliamentary proposal to approve Sign Language as official language), ${ }^{11}$ the LGBT movement (through same-sex marriage (Law 13/2005) and the Gender Identity Law (2007), 12 etc. (Platero 2006, 103). My analysis will focus on two of the laws: Gender equality laws and same-sex marriage law in order to explore the implications of intersectional and inclusion perspectives, showing which inequalities are identified and if there are references to mutual interactions between them, and in what terms. These two cases will be subject to questions such as: Who are the target of these policies? Do the policies take multiple discrimination into account in any way? What kind of diversity is recognized? In what strategies of feminist political action might they be utilized? Which critiques are more relevant for pursuing a wider understanding of citizenship? The answers would provide us with a definition of equality and strategies in which the policies are located.

\section{TOWARDS BROADENING THE DEFINITION OF EQUALITY}

As I mentioned earlier, equality policies in Spain have grown increasingly important since their origin in 1983 with the creation of the Instituto de la Mujer and more recently with the creation of the General Secretariat for Equality Policies (2004). These equality bodies have mainly used equality plans as working tools (from 1988 to the present) with a recent glide toward equality laws (from 2002 and onwards). The role 
played by equality plans has been reinforced $^{13}$ by the recent shift to hard politics with the promotion of equality laws in five regions ${ }^{14}$ and the national law for effective equality ${ }^{15}$ between women and men 3/2007 approved in March 2007.

Bustelo and Peterson $(2005,2)$ stated that in analyzing the five regional laws, ${ }^{16}$ they have found a very different use of the same policy instrument, indicating that the status of a law does not entail that the laws have a similar or equivalent content. Also, there has been a promotion of specific initiatives that focus mainly on women's concerns - violence, employment, family, social exclusion, etc. - specific parity and electoral laws that promote women's quotas, ${ }^{17}$ and the creation of equality units to implement the gender mainstreaming strategy in regional governments: Andalusia: 2001 and Cantabria: 2004.

Out of all these initiatives, this paper will be looking at hard politics: The regional equality laws ${ }^{18}$ and the national equality law mentioned. My analysis includes these six policy documents and will revolve around the following questions: To what extent is intersectionality taken into account, who are the women targeted and how, what is the definition of women, and how are inequalities and their implications addressed?

Only the Basque 4/2005 equality law and the national equality law $3 / 2007$ mention 'multiple discrimination.' The Basque text develops a large description of different inequalities and identities of women (race, color, ethnic background, language, religion, political opinions and others, national minorities, class, birth, disability, age, sexual orientation and any other social or personal condition (see p. 24815). In addition, the Basque law acknowledges multiple discrimination and establishes an interest in assisting women who are affected by multiple discrimination, guaranteeing them basic social rights and developing studies to assess the impact of multiple discrimination. The
Basque Law is rather different from the rest of the equality documents examined: It is in accordance with the III Basque Equality Plan (1999) in which multiple discrimination is addressed, including not only the diagnosis (goals and analysis) but also the prognosis of this problem (actions). Thus, multiple discrimination is part of the problem and linked to the definition of equality, and it is present in the actions developed both in the plan and the law.

The national equality law recently promoted (March 22, 2007) by the socialist government intends to implement the European Directive on employment and fight against discrimination and sexual harassment, reforming more than nineteen legislation texts regarding the access to public employment and social security benefits. It also contributes with the amplification of maternity leave in the event of premature birth and other special cases. The legal text enhances the understanding of gender and sexual harassment at the workplace, including not only gender discrimination, but also ethnicity, religion, beliefs, disability, age, and sexual orientation (by promoting a modification of the Workers' Statute-law 1/1995, Additional disposition ten, see BOE $71,23 / 03 / 07$, p. 12628). This law project for equality refers to "the singular difficulties that occur to those collectives of women in special vulnerability" (pp. 12611, 12615), single parent families (art. 27 on housing), rural women (art. 26 on rural development), women who suffer violence, etc. (p. 12630). The proposal recognizes that direct and indirect discriminations take place concerning different inequalities, also including marital status, being part of a trade union, having relatives at work, speaking the national language, etc. The text proposes that entrepreneurs could be prosecuted when discrimination on these grounds takes place (p. 12633). The only explicit reference to 'multiple discrimination' is located in art. 20c concerning the adaptation of statistics and studies, stating 
that public authorities have to design indicators that allow the acknowledgement of other variables that generate multiple discrimination (p. 12616).

The law shows the government's concern with the reconciliation of labor and family life, introducing rights for men by virtue of their role as fathers. The law recognizes paternity leave rights with 15 days that will become 4 months by 2013 . The most controversial part of the law has been the obligation for all political parties to present party lists for next elections in the local, regional, and national realms. Women must make up at least $40 \%$ and be represented once in every five names, so that they are not merely present on the bottom of the list.

The law has faced controversy and resistances from both conservative realms and part of the feminist movement. This law has been contested by feminist organizations for not consulting the feminist movement, while the conservative party claimed that it will claim unconstitutionality because of the parity list obligation for all elections, stating that " $[\mathrm{i}] \mathrm{t}$ is the first time that the electoral law has been reformed without the support of two majority political groups $[\ldots]$, the law is absurd and will result in exclusion since it makes it impossible for a party to have all women candidates."19 In fact, the Conservative Party (PP) recently presented a unconstitutionality appeal against Equality Law 3/2007 (June, 20th 2007), based on their disagreement with parity electoral lists.

The rest of the documents do not take into account that inequalities take place simultaneously and with specific influences on each other; instead these laws only mention different inequalities, listing them as isolated. Some regions are more inclusive toward disability or migration, while there are resistances to include inequalities such as sexuality in general and sexual minorities in particular. I will argue that these laws all but the Basque law and the national equality law 3/2007 - are quite conservative, since their scope is limited to pointing out minimum differences among women, such as the degree of women's involvement in associations (Navarra ${ }^{20}$ Law), but also these laws emphasize women's role as mothers (Galician ${ }^{21}$ and Valencia ${ }^{22}$ Laws) and caregivers $^{23}$ of dependent relatives (elderly, disabled, children). The support to women's roles as mothers and caregivers relates to disability, age, and other inequalities, but only when women are instrumental to the care of others. These documents show that women are not the subjects that may be represented as elderly or disabled or dependent, therefore policies do not take them into account as a source of needed action. This is also the case for the link established between women and poverty ${ }^{24}$ in the Valencia law which is articulated as if poverty were only an issue concerning divorced women. Other kinds of sources or problems linked to poverty are not pointed out.

Each one of these laws includes violence against women as a key issue. Some of them provide assistance for employment, housing, etc. as the only concerns for women's poverty or class situation. Somehow, women are ageless and are not dependent. Poverty is only recognized or legitimate when violence or divorce take place.

Equality here targets mostly women (see the reference to male professionals in the Basque text $)^{25}$ and the role of men as fathers in the national equality law $3 / 2007$, and these women are defined differently from one region to the other, also compared to the national law proposal. In some of these texts there are a number of identities, inequalities, or situations that are recognized and others that hardly ever emerge. Maternity and women who suffer violence are present widely, recognizing the role of the State acting and providing services. Other women such as women with disabilities, rural women, or single mothers, or inequalities based on e.g. ethnicity, reli- 
gion, beliefs, etc. are only present in some laws.

Reviewing the Spanish equality laws selectively, all of them are imbedded in the 'inclusion' strategy, using Judith Squires' political strategy classification (1999). The problem is located in the limited definition of woman and the principle of equality; the policies aim to include women, thereby reinforcing the binary categorization. The problem is thought to be "exclusion;" not the gender order, the male norm, mens absence or the binary order. The policies tend to present themselves as impartial, i.e. conceiving people as autonomous, and espouse an equality politics; this strategy seeks gender-neutrality (Verloo 2005). Thus, the solution is limited to acknowledging those women who have been absent from state action, widening the scope of equality policies to include women with disabilities, migrant women, rural women, elderly women, and to some extent lesbians (Platero, 2007b). ${ }^{26}$

The Basque law differs somewhat from the rest by acknowledging multiple discrimination and some inequalities that are not identified by any other regional law, such as non-normative sexuality. Nonetheless, the Basque law does not intend to change the male norm or dismantle the gendered binary order as it lacks an indepth analysis of the effects of intersectional discrimination on Basque women. Therefore, it also remains within the inclusion strategy, in a wider perspective than the rest of texts. The National Equality Law 3/2007 is quite similar to the Basque text in the extent to which it allows a certain recognition of women's diversity, mentions multiple discrimination, but does not introduce major changes in men's roles, nor intentions to change society as a whole. In this sense, both texts are more progressive than the rest, but they still exemplify an inclusion strategy.

Looking at the equality law texts, intersectionality only means taking into account different but limited identities. Little attention is paid to the meaning of intersectionality as simultaneous and mutually influenced inequalities that affect women, while men are hardly mentioned by equality policies unless referred to as parents or professionals in only two texts. Instead, 'monofocal' attention is paid to race and ethnicity mostly understood as an immigration problem, whilst new attention is directed toward disability and independent life, rural women, etc. The one vulnerability that every policy takes into account and pays large attention to is the situation of women as victims of violence (and its influence on and relation to employment, housing, etc.)

In this sense, Spanish gender equality policies are firmly rooted in limited change of structures and policy frames, the most 'transformative' trends being those policy texts in which lesbians are included, as well as immigrants, the disabled, women from different ethnicities and religions, etc. The political strategy embedded in these policies is "inclusion," not so much the transformation of social structures, although the contrary is alleged in the goals and mission of many policy documents. Completely absent is the 'displacement' strategy.

Therefore, even in the most progressive regions - where gender equality policies comprise participatory processes that include feminism, that count on feminist lesbians in the administration, where LGBT organizations are relevant, where left-wing parties introduce social movement demands into their political programs, where activists are doubly involved (in NGOs and political parties), and the European framework functions as reference, etc. - the real expectations of social change are limited to inclusion and to some extent reversal.

\section{The Hidden Sides of Equality IN SAME-SEX MARRIAGE}

On June 30th 2005, the Spanish Parliament approved Law 13/2005 allowing for 
changes in the Civil Code on the subject of marriage. It put Spain in the spotlight of the international media by promoting formal equality for lesbians and gays. During the last years of the dictatorship (1975) and the transition to democracy, the main battles for gay rights had moved from eliminating legal obstacles that punished homosexuality to the achievement of a new Penal Code (1995) that recognized homophobia as a crime to the later fight for kinship recognition. The demand for same-sex marriage was first constructed as same-sex partnership proposals.

Over time, from a spectrum of potential LGBT demands, certain issues have been constructed by key LGBT activists as more relevant and urgent. We can distinguish two major periods: In the first period, from the beginning of the 1990s to 2002 , partnership rights emerged as a central demand, although there was no consensus about this amongst LGBT organizations. These demands translated into the achievement of partnership laws in eleven regions out of a total of nineteen (1998-2005). However, the demand for partnership rights (for stable couples) won support and mobilization over time, adopting different names (civil unions, the facto unions, stable partnerships, etc.) and a different extent of rights (adoption, inheritance). During the second period, the National Federation of LGBT organizations (FELGT) and those political actors who supported same-sex marriage had an increasing political impact, leading to a proposal for same-sex marriage that became Law 13/2005 reforming the Civil Code and constituting the starting point of formal equality for Spanish gays and lesbians.

Same-sex marriage did not emerge 'out of the blue': It was the culmination of a series of demands from social movements on the left (including political parties and policy makers) who perceived a window of political opportunity. The Leftist Party Izquierda Unida, IU - was crucial in intro- ducing the most progressive proposals in their policies and manifestoes, contributing to the emergence of LGBT policy issues on the political stage. But the main role has been played by the Socialist Government (Partido Socialista Obrero Español, PSOE) which has used marriage as a source of political polarization, incorporating LGBT politicians with double activisms (Platero 2007). Some of these gay politicians have used gay marriage as the central issue of their careers. Leftist parties are constructing a vision of citizenship and democracy that implies a greater commitment to social movements (Calvo 2005, 33).

As mentioned earlier, the PSOE government set equality as a priority, using gay marriage (2005) and the law on gender identity (2007) as symbols of their equality ideology (Platero 2006, 103). But too many expectations have been invested in the achievement of same-sex marriage: Equality has limits. Same-sex marriage has been represented as the 'ultimate thing' for gay (and sometimes also for lesbian) rights. It has been constructed not only as a symbol of formal equality but the fulfilment of citizenship. The law is presented as either too transgressive from a conservative point of view or as a source of modernity and symbol of formal equality and progressiveness from a Socialist perspective. Little has been said on the limits concerning intersectional and gender perspectives: How does same-sex marriage affect lesbian, transgender, sans papiers, migrant, poor, (dis)abled, HIV-positive and other disenfranchised individuals? There has hardly been any discussion concerning the impact of marriage on diverse citizenship.

Also in Spain, the context in which same-sex marriage emerged led to binary standpoints, leaving little room to problematize the institution of marriage (Butler 2002). Some critical voices were mostly linked to minority lesbian feminist groups and queer activism. For instance, the Catalonian Lesbian Feminist Group stated that 
"marriage represents the community's refusal to assume responsibility for people's needs and the abandonment of relations of dependency to the private sphere $[\ldots][\mathrm{I}] \mathrm{t}$ represents an excessive regulation of relations between adults. Marriage can serve to make the existence of lesbians visible, but at the same time it contributes to render invisible and to erode other types of relations that we establish $[\ldots]$ "27 They point out the difficulties for lesbians to be out and visible, making marriage a less attractive institution than for gay men, along with their criticism of marriage as a contract that reinforces the possibility for people to maintain abusive or exploitative relationships (VVAA 2004). Paco Vidarte (2005) said that gay men and lesbians no longer share spaces and protests with other minorities such as transgender people, immigrants, gypsies, inmates, sex workers, and HIV-positive individuals, remarking the lack of interest and resources for AIDS/HIV in the current policy making. Pedro Carmona (2005) and Raquel Platero (2006) note that the political debate gives the impression that all LGBT movement demands are met through gay marriage, forgetting other relevant issues such as homophobia in education, the stereotyped treatment of LGBT issues in the media, etc. The women squatters' house 'La Karakola'28 supported the idea of a gay, lesbian, pansexual, and convenience marriage to the extent that it loses its heteronormative meaning. They support the recognition and full rights for all people and families of any sort and nationality, highlighting the situation of those individuals sans papiers and the need for free mobility.

These critiques failed to gain visibility in the debates on the impact of marriage on (disenfranchised) individuals and other forms of organization and citizenship. Most representations show that the debate on gay marriage has been monopolized by a response to the conservative realms and is presented as a 'gay thing.' The center of resistance has used the gay stereotypes of child abuse, pedophilia, promiscuity, etc. that have little to do with lesbians, the needs of migrant LGBT individuals, or the elderly. Limited attention has been paid to the differential impact of the marriage institution on women, migrants, non-white, non-urban, non-abled, etc. In the Parliamentary debate prior to the same-sex marriage law, lesbians were barely mentioned, and nothing much was said on marriage and migration, the elderly, disability, or any other inequality. On the other hand, samesex marriage has the potential to reinforce principles of monogamy, cohabitation, and the sharing of economic assets which many lesbians challenge in their everyday lives. In particular, article 68 of the Civil Code states that the spouses must live together, be loyal and help each other, share domestic tasks and care of children, the elderly, and dependent individuals. Furthermore, the impact of same-sex marriage on lesbians in Spain has not been investigated and was not an explicit concern for politicians and activists during the run-up to the amendment of the Civil Code (Platero 2007a).

The only mention of the specific situation of lesbians was made by the Catalonia Leftist Party proposing changes in the Civil Register allowing two women to be inscribed as mothers of a child. ${ }^{29}$ After the approval of the law, many judges and civil servants claimed conscious objection, while the first problems of individuals trying to marry non-citizens ${ }^{30}$ arose: With some time of chaos, the law had to be interpreted to be applied in the same way as to heterosexual couples. In addition and contrary to the spirit of the $13 / 2005$ law, same-sex parents are not recognized automatically as heterosexual parents, but have to start an adoption process. The Socialist government committed $^{31}$ itself to recognizing both lesbian women in a couple as mothers through the revision of the Law of Assisted Reproduction (art. 6) which took place 
with the Gender Identity Law, approved on March $15^{\text {th }} 2007$.

In January 2007, The National Statistics Institute (INE) published the data on same-sex marriage concerning the period July-December 2005. It showed that samesex marriages amounted to only $1,8 \%$ of the total number of marriages in Spain, mostly among men (two thirds, 923 weddings), whereas lesbians were less likely to marry (352 weddings). In addition, samesex marriages with a foreign spouse were twice as frequent (349 marriages) as heterosexual marriages. Some authors and activists claim that during the first months, getting married was not an easy task due to the resistance of conservative judges and city halls, but also that the institution of marriage is not as attractive to gays in general and to lesbians in particular, unless you can benefit by obtaining residence or protecting your children or wealth. It is no surprise that gay marriages were more likely to take place in large cities such as Madrid $(20,2 \%)$, Barcelona $(17,2 \%)$, and Valencia $(10,7 \%)$.

The law defined equality as a matter of making the institution available to same-sex couples. The problem is diagnosed as pertaining to same-sex unions exclusively, and therefore, the solution only alleviates this diagnosis. Nothing is said on the situation of other citizens that may avail themselves of same-sex marriage. The institution is only transformed to allow same-sex marriage, but no other structural changes take place. The lack of a gender perspective or an intersectional perspective implies an assimilationist and liberal view of gay marriage. It lacks all criticism made by seventies' feminism of the social contract and compulsory heterosexuality and the current critical feminist debate on marriage ${ }^{32}$ whose authors have pointed out the biased effects of marriage on disenfranchised individuals for whom a more profound intersectional analysis is required. Marriage is not neutral, when structural inequalities of e.g. race, gender, class, and ethnicity persist and reemerge as side effects and maybe reinforcing potential exclusion (Platero 2007a).

I would like to bring your attention to the fact that currently these potential intercrossing effects are not sufficiently discussed.

According to the questions posed in my analysis, Law 13/2005 can be said to target mostly gay men, because it fails to introduce specific actions addressing multiple discrimination or pay any attention to other inequalities such as gender or age. The law text discriminates against lesbians by not acknowledging their possible role as mothers, which can be observed in two concrete situations: firstly, law 13/2005 does not resolve the situation of automatic recognition of both mothers, as it is the case of heterosexual marriages. Secondly, the donation of ova has to be anonymous, therefore the mutual donation of ova between married women is not allowed in Spain, as it is not allowed among friends, relatives, etc. (Law 35/1988 and Royal Decree 412/1996). Same-sex marriage has been presented as a matter of achieving citizenship rights by including some individuals disenfranchised by their sexual orientation, referring clearly to Squires' strategy of inclusion. Some voices claim that including gay and lesbian individuals in a traditional institution will transform them, but the law does not intend to change society, nor the gender and sexual order.

\section{CONCLUDING REMARKS}

'Equality' seems to be a relevant issue in current Spanish policy making: Same-sex marriage and equality policies are on the top of the socialist government agenda to the extent that they are being instrumentalized by foreign politicians in their political campaigns. The approval of these policies does not imply a total consensus about neither the demand nor the acceptance, but it has generated a mobilization of political 
parties, civil organizations, and other political actors that has resulted in new laws (2003-07).

The recent changes in Spanish socio-economic demography put some problems on the political agenda such as migration, the elderly, dependent individuals, gender violence, gay rights, etc., generating a space in which multiple discrimination may emerge as a public problem. Once these problems have become part of the political agenda, the State has assumed responsibility for acting on discrimination based on gender, sexuality, disability, migration, etc. with specific policies and laws.

While the actions of the Spanish State, such as the development of equality policies and same-sex marriage, have achieved international significance, the notion of equality is limited in that it does not acknowledge the particular needs of different individuals, which is why an intersectional analysis is relevant. Gender equality policies are directed mainly toward women, progressively broadening the definition of women to include different inequalities, but lacking a profound intersectional analysis that results in specific actions for disenfranchised individuals and their unique strategies of resistance. These policies reflect a narrow definition of their actions: Women are mostly interpreted as mothers, wives, and caregivers. Same-sex marriage law in Spain has been conceptualized within a 'neutral' perspective, mainly addressing gay men and ignoring other specific needs or inequalities of 'other' citizens. The neutral definition of the subject of equality is problematic, since it lacks a multiple understanding of inequalities, leading to further discriminations within groups and 'second-class' citizens.

Exploring the political strategies informing these law texts and following Squires' terminology, 'inclusion' is the only strategy that policy makers have developed so far. The laws are not drastically changing the definition of equality, nor do they offer a new perspective on social changes, because they fail to recognize recent intersectional theorization. The fact that some regions allow more resources and relevance in their policies while rendering other inequalities invisible indicates that policy makers differ in their awareness of various inequalities. In the law texts, some topics are widely recognized, e.g. motherhood or violence against women, while others are low-profile, e.g. sexuality in general or lesbianism or disability in particular. Regrettably, little is done to understand inequality as intersectional.

The level of modernity and progressiveness that these laws suggest is negligible: The gender and sexual order remains untouched. By including the "others" to a certain degree, i.e. by recognizing identities and some structural inequalities, no other profound changes have been promoted. The current scenario looks promising in terms of future development of policies and public representation for minorities, provided that experiences with gender, sexuality, and disability policies and politics are incorporated.

The extent to which policy makers will be able to apply their understanding of equality and introduce intersectional perspectives into the law texts remains uncertain, and social movements have not yet been articulate enough to bring up intersectional demands and put them on the political agenda such as concrete demands for bisexual, transgender or lesbian women concerning equality policies, health provisions, etc. In this sense, academics and activists can play an important role in generating debates that introduce new concepts describing our experience and articulate intersectional and transformative demands.

\section{Noter}

1. The article partly results from the MAGEEQ research team on "Policy frames and implementation problems: The case of gender mainstreaming" (see www.mageeq.net and www.proyec- 
tomageeq.org). The Spanish case study included an analysis of discourses of sexual orientation within the gender equality policies (1995-2005) as well as the study of gay and lesbian rights in Spain.

2. Firstly, there are public services for homosexual and transsexual people (such as Berdindu, The Service for Homosexuals and Transgender Individuals at the Comunidad de Madrid, Énfasis, etc.) Secondly, there is legislation regulating partnership rights for both same-sex and opposite-sex couples in twelve out of sixteen regions, changes in the Civil Code to legalize same-sex marriage (law $13 / 2005$ ), and the Gender Identity Law (approved March 15 th 2007). Further local policies aim to eradicate discrimination on the grounds of gender and sexuality (Coslada, Barcelona etc). Lastly, specific policies for gays, lesbians, and transgender individuals are developed, such as the Catalonian Interdepartmental Plan (2006) (see Platero 2007b).

3. The Basque Equality Unit is called 'Emakunde' or 'Basque Women's Agency,' promoting the 3rd Positive Action Plan for Women in the Basque Country (III Plan de Acción Positiva para las Mujeres de Euskadi, 1999).

4. The Catalonian Equality Unit is called 'Catalonian Women's Agency' (Institut Catalá de les dones) and they promote the 5 th Action Plan for the development of policies for women ( $V$ Plan de Acción y Desarrollo de politicas para Mujeres en Cataluña, 2005-2007).

5. See for instance Romero Bachiller, Carmen (2006): "Poscolonialismo y Teoría Queer", in David Córdoba et al.: Teoria Queer. Politicas bolleras, maricas, trans y mestizas. Egales, Madrid; hooks (2004): Otras inapropiables: feminismos desde las fronteras. Traficantes de sueños, Madrid; Platero, Raquel (2007): "Intersecting gender and sexual orientation. An analysis of sexuality and citizenship in gender equality policies in Spain", in 'Contesting Citizenship: Comparative Analyses.' CRISPP $10(4)$.

6. Amnesty International in Spain uses the term and the concept in some reports, such as the 2004 report on Violence and Discrimination against Lesbians and Bisexual Women ('No más violencia ni discriminación contra mujeres lesbianas y bisexuales').

7. Most Spaniards still regard the ideal family to consist in a man and a woman sharing domestic tasks and childrearing (Cruz Cantero 1995, 18). The egalitarian family model is even more popular/prevalent among young Spaniards aged 15-29 (CIS 1999).

8. Cué, Carlos E. (17/09/2006): "Ségolène Roy- al alaba el 'modelo español' en política de igualdad", in El Pais, p. 30.

9. Ley Orgánica 1/2004 de Medidas de Protección Integral contra la Violencia de Género, Boletín Oficial del Estado de 29 de Diciembre de 2004, nº 313. This law implies that violence committed by men is treated differently than that committed by women and has been largely demanded by the feminist movement since 1997.

10. The Government Cabinet approved on December, 14th, 2006 the law 39/2006 concerning the promotion of Personal Autonomy and Atention to people in sittuations of dependency.

11. The Government Cabinet approved the law proposal concerning the recognition of Sign Language as an official Spanish language on January 13th 2006.

12. The Government Cabinet approved the Law regulating changes in the registration of sex on March lst 2007.

13. The national equality law articulates the implementation of equality plans, not only in public administrations, but also in all companies with more than 250 employees.

14. Navarra: 2002, Castilla y León and Valencia: 2003, Galicia: 2004, and the Basque Country: 2005.

15. Ley Orgánica $3 / 2007$, de 22 de marzo, para la igualdad efectiva de mujeres y hombres.

16. Most of these laws (with the Basque exception) are written as a set of proposals with very general goals that are closer to equality plans than a legal text (Platero 2005). Regarding the great diversity of these laws, some authors such as María Durán, Vice-president of the European Women Lawyers Association, pointed out that from a legal perspective, only the Basque text can be considered a law (at the time the national law proposal was still underway). María Durán made this statement during her conference at a seminar titled "The achievement of equality" at the International University Menéndez Pelayo (Santander), August 2005.

17. Law $11 / 2002$, Balear Islands, and Law 11/2002, Castilla-La Mancha.

18. Names and references of the Equality Laws in chronological order: Ley Foral 33/2002 de 28 de Noviembre de fomento de la igualdad de oportunidades entre mujeres y hombres en Navarra. Ley $1 / 2003$ de 3 de marzo, de igualdad de oportunidades entre Mujeres y Hombres en Castilla y León. Ley 9/2003, de 2 de abril, de la Generalitat Valenciana, para la igualdad entre mujeres y hombres. Ley 7/2004 de 16 de Julio gallega para la igualdad de mujeres y hombres. Ley 4/2005, de 
18 de febrero, para la Igualdad de Mujeres y Hombres en el País Vasco.

19. Europa Press (15/03/2007): “El Congreso aprueba la Ley de Igualdad con la abstención del PP. Zapatero defiende una norma que hace justicia a las mujeres", in El País.

20. The Navarra 33/2002 law only distinguished between those women organized into associations and those who lack this experience by stating that women's associations will be promoted by "taking into account those areas in which women of Navarra have a lower associative level" BOE n.13, January 15th 2003, p. 1881.

21 . In article 3 , women's right to maternity is treated as a social need that the state recognizes and promotes. BOE n.228. September 21 st 2004, p. 31572 .

22. BOE n.110, May 8th 2003, p. 17427.

23. Valencia 9/2003 Law. Chapter five on Welfare and family develops article 25 on the care of dependent people: The regional administration will provide the resources needed to care for children, elderly, and disabled people, facilitating the access to services nearby their homes, facilitating the incorporation of women to the labor market." 24. Valencia 9/2003 Law. Article 26 on feminization of poverty mainly concerns divorced or separated men neglecting to pay for their children's expenses. BOE n.110, May 8 th 2003, p. 17431.

25. Mostly in articles 35 and 47 , remarking on the role of public administration in promoting a new role for men as regards domestic chores and the reconciliation of personal, familial, and labor realms.

26. Limited to the Equality Plans of the Basque Country (1999), Canary Islands (2003) and Catalonia (2005) and the Equality laws of the Basque Country (2005) and Castilla y León (2003). For further information see Platero 2005.

27. See the article "Beyond Marriage" (2004) accessible at (last access July 10, 2007):

http://www.lesbifem.org/textos/matrimoni/mat rimoni_ENG.html.

28. See the article titled "Weddings agency" accessible at (last access July 10, 2007):

http://www.sindominio.net/karakola/matrimonios/casate.htm.

29. See the speech of Rosa M. Bonás Pahisa. Congress Diary. Plenary Session 98, June 30th 2005, on the Law Project modifying the Civil Code on the subject of marriage rights.

30. El País, 06-07-2005. Un juez rechaza casar a dos hombres porque uno de ellos es extranjero. Lluís Pellicer.

31. de Cozar, Alvaro. El Gobierno revisara la discriminación de las lesbianas con los bebés 'in vitro' (El País, 18/10/2006, p. 41).

32. See for instance Rosemary Auchmuty (2004), Susan Boyd and Claire Young $(2003,2006), \mathrm{Ni}^{-}$ cola Baker (2006), Davina Cooper (2001), Carl Stychin (2006), etc.

\section{LITTERATUR}

- Agnew, Vijay (2003): Gender and Diversity: A Discussion Paper. Intersections of Diversity Seminar. Canada.

- Auchmuty, Rosemary (2004): "Same-Sex Marriage Revived: Feminist Critique and Legal Strategy", in Feminism of Psychology 14/1, 101-126. - Bacchi, Carol L. (1999): Women, Policy and Politics. The Construction of Policy Problems. Sage, London.

- Barker, Nicola (2006): "Sex and the Civil Partnership Act: the future of (non) conjugality", in Feminist Legal Studies 14(2), 241-259.

- Boyd, Susan, and Claire Young (2006): "Losing the Feminist Voice? Debates on the Legal Recognition of Same Sex Partnerships in Canada", in Feminist Legal Studies 14(2), 213-240.

- Bustelo, M. and E. Peterson (2005): The Evolution of Policy Discourses and Policy Instruments within the Spanish State Feminism. A Unified or Fragmented Landscape? Worshop: "State Feminism and Women's Movements: Assessing change of the last decade in Europe". ECPR Workshops. Granada (Spain). April 2005.

- Bustelo Ruesta, María (2004): La evaluación de las politicas de género en España. La Catarata, Madrid.

- Bustelo, María, Emanuela Lombardo, Raquel Platero and Elin Peterson (2004): Country Studies: Spain. Institut für die Wissenschaften des Menschen, Vienna.

- Butler, Judith (2002): "Is Kinship Always Already Heterosexual?", in Differences: A Journal of Feminist Cultural Studies 13/1, 14-44.

- Calvo, Kerman (2005): "Matrimonio homosexual y ciudadanía", in Claves de la razón práctica 154, 32-40.

. Carmona, Pedro (2005): “Olvidos”, in Diagonal, July $21^{\text {st }}-$ August $31^{\text {st }}, 38$.

. CIS (1999): "Los jóvenes de hoy", in Boletín Datos de Opinión 19.

. Crenshaw, Kimberlé (1989): "Demarginalizing the Intersection of Race and Sex: A Black Feminist Critique of Antidiscrimination Doctrine", in Femi- 
nist Theory and Antiracist Politics. University of Chicago Legal forum, Chicago, 139-167.

. Crenshaw, Kimberlé (1994): "Mapping the Margins: Intersectionality, Identity Politics, and Violence Against Women of Color", in M. Fineman and R. Mykitiuk (eds.): The Public Nature of Private Violence. Routledge, New York, 93-118.

- Cruz, Jacqueline and Barbara Zecchi (eds.) (2004): La mujer en la España actual. ¿Evolución o involución? Icaria, Barcelona.

- Escario et al. (1996): Lo personal es político. El movimiento feminista en la Transición. Ministerio de Asuntos Sociales, Instituto de la Mujer, Madrid. - Larumbe, María Angeles (2001): "El feminismo en la Transición Española", in Una inmensa minoría influencia y feminismo en la transición. Segardiana, Prensas Universitarias de Zaragoza, Zaragoza, 139-196.

. Osborne, Raquel (2006): "Entre el rosa y el violeta. Lesbianismo, feminismo y movimiento gay: relato de unos amores difíciles", in Labrys, études féministes/ estudos feministas. Accessible online: http://www.unb.br/ih/his/gefem/labrys10/espanha/raquel.htm\#_ftnrefl.

- Platero, Raquel (2005): Are lesbians considered women by Spanish femocrats? The representation of non-normative sexualities in the national and regional equality policies. 3rd ECPR Conference Panel No: 8 - Equality and Diversity: European Perspectives, Budapest, September 2005.

· Platero, Raquel (2006): “¿Invisibiliza el matrimonio homosexual a las lesbianas?”, in Orientaciones: 10. Fundación Triángulo, Madrid, 103-120.

- Platero, Raquel (2007a): "Love and the State:

Gay marriage in Spain”, in Feminist Legal Studies $15(2)$.

- Platero, Raquel (2007b): "Intersecting gender and sexual orientation. An analysis of sexuality and citizenship in gender equality policies in Spain", in Contesting Citizenship: Comparative Analyses.
Critical Review of International Social and Political Philosophy, CRISPP 10 (4).

- Squires, Judith (1999): Gender in Political Theory. Polity Press, Cambridge.

- Stychin, Carl F. (2006): "Not (quite) a horse and carriage. The Civil Partnership Act 2004", in Feminist Legal Studies 14(2), 79-86.

- Symington, Alison (2004): "Intersectionality: a tool for gender and economic justice", in Women's rights and economic change, Association for Women's Rights in Development. Facts \& Issues (9), 1-8. Accessible online: http://www.awid.org/publications/primers/intersectionality_en. pdf.

- Verloo, Mieke (2004): Mainstreaming Gender Equality in Europe. A frame Analysis Approach. Conference of the Europeanist, Chicago, March 2004.

- Verloo, Mieke (2005): "Displacement and Empowerment: Reflections on the Concept and Practice of the Council of Europe Approach to Gender Mainstreaming and Gender Equality", in Social Politics: International Studies in Gender, State \& Society 12(3), 344-365.

. Vidarte, Paco (2005): “'Dhivorcio' y matrimonio gay", in Diagonal, July $21^{\text {st }}-$ August $31^{\text {st }}, 38$. - VVAA (2004): Otras inapropiables: feminismos desde las fronteras. Traficantes de sueños, Madrid. - Young, Claire and Susan Boyd (2003): "From Same Sex to No Sex? Towards Legal Recognition of (Same Sex) Relationships in Canada", in Seattle Journal of Social Justice 1(3), 757-793.

Raquel Platero Méndez

Reseacher

Departamento de Ciencia Política y de la

Administración II, Facultad de Ciencias

Políticas y Sociología.

Universidad Complutense de Madrid 